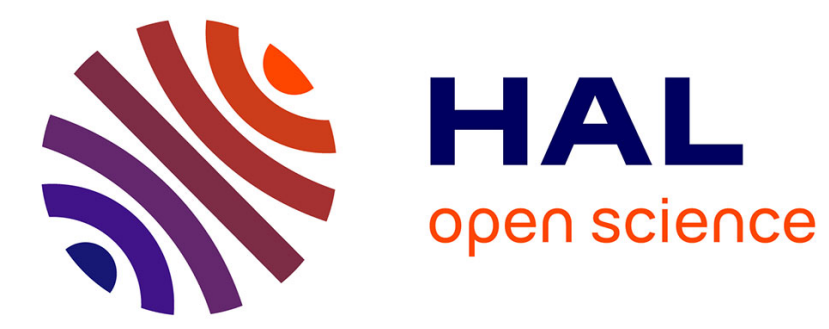

\title{
Basque Pronouns and Relativized Locality
}

Georges Rebuschi

\section{To cite this version:}

Georges Rebuschi. Basque Pronouns and Relativized Locality. 115-144 (CILT, 105), J. Ortiz de Urbina \& J. Hualde (eds) - Benjamins Publishing, 1993. artxibo-00000062

HAL Id: artxibo-00000062

https://artxiker.ccsd.cnrs.fr/artxibo-00000062

Submitted on 6 Feb 2006

HAL is a multi-disciplinary open access archive for the deposit and dissemination of scientific research documents, whether they are published or not. The documents may come from teaching and research institutions in France or abroad, or from public or private research centers.
L'archive ouverte pluridisciplinaire HAL, est destinée au dépôt et à la diffusion de documents scientifiques de niveau recherche, publiés ou non, émanant des établissements d'enseignement et de recherche français ou étrangers, des laboratoires publics ou privés. 
GR, 1993. 'Basque Pronouns and Relativized Locality; in J. ORTIZ DE URBINA \& J. HUALDE (éds.), Generative Studies in Basque Linguistics; Amsterdam, Benjamins (CILT, 105),

115-144.

\section{BASQUE PRONOUNS AND RELATIVIZED LOCALITY \\ Georges Rebuschi, Université de la Sorbonne Nouvelle \\ \& CNRS (URA 1055 \& GDR 120)}

\section{Introduction.}

In this paper*, I will defend the idea that the degree of cross-linguistic variability allowed by the relativized definitions of Governing Categories (henceforth GCs) for pronominals and anaphors propounded by Huang (1983), Chomsky (1986) and Aoun (1986) is not sufficient, as was already noted by Manzini \& Wexler (1987) and Koster $(1985,1987)$. Moreover, the Basque data $^{1}$ to be analyzed will also show the superiority of the latter's theory over Manzini \& Wexler's. Finally, I will have to introduce slight modifications into Koster's theory, allowing for the presence of PROs to specify the maximal projections of dyadic Ns and Ps (these specifiers being submitted to the licensing condition that the $X^{\max }$ which contains them be the predicate of a stative predication), so as to account for data which had already been noted in e.g. Rebuschi (1988, 1989), but had been left unexplained.

\section{Background.}

1.1. Chomsky's (1981) classical Binding Theory was mainly devised to account for those cases where pronominals and anaphors were in complementary distribution in a fairly local domain, as in (1a-c) - where this local domain, the pronoun's GC, is indicated by square brackets although the notion of Accessible SUBJECT also took care of some (highly marginal, cf. Yang (1982), Koster (1985)) cases of long-distance binding, in which the distributional complementarity was not respected, as in (d). Consequently, the examples in (1) were explained:

(1) a. [They saw them ${ }_{\mathrm{i} / *_{\mathrm{j}}} /$ themselves $_{\left.\mathrm{i} / *_{\mathrm{j}}\right]}$

b. They ${ }_{i}$ bought [my pictures of $*$ themselves $/$ them $_{\mathrm{i} / \mathrm{j}}$ ]

c. [They $y_{i}$ bought pictures of themselves ${ }_{i} /$ them $\left._{*}\right]_{i}$

d. [They expected that pictures of themselves $_{i} /$ them $_{i / j}$ would be on sale]

However, such examples as (2), borrowed from Huang (1983), (3), from Chomsky (1986: 170 ), or (4), from Aoun (1986: 35) could not be dealt with:

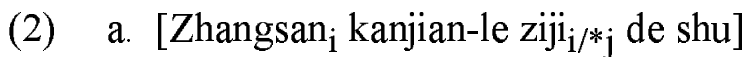
Zh. saw self 's book

'Zhangsan saw his (own) book'

b. [Zhangsan ${ }_{\mathrm{i}}$ kanjian-le $\mathrm{ta}_{\mathrm{i} / \mathrm{j}}$ de $\mathrm{shu}$ ]

'Zhangsan saw his book'

(3) a. [The children like each other $_{i}$ 's friends]

b. The children like $\left[\right.$ their $_{\mathrm{i} / \mathrm{j}}$ friends]

(4) a. [Zhangsan ${ }_{\mathrm{i}}$ shuo ziji $\mathrm{i}_{\mathrm{i}}$ hui lai]

$\mathrm{Zh}$. said self will come

'Zhangsan said (that) self would come'

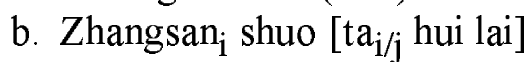

'Zhangsan said (that) he would come'

1.2. The first versions of relativized locality relied on the intuition "that the relevant governing 
category for an expression $\alpha$ is the least CFC [Complete Functional Complex - roughly, what was classically known as a Cyclical Category: NP or S] containing a governor of $\alpha$ in which $\alpha$ could satisfy the binding theory with some indexing (perhaps not the actual indexing of the expression under investigation)" [Chomsky, (op. cit : 171); the italics are mine]. A minimally relativized definition of GCs ensues, which typically materializes when the pronouns are the subjects of the smallest cyclic category or CFC which contains them ${ }^{2}$ : given the familiar geometrical representation of subjects, such entities cannot be c-commanded by anything inside the minimal CFC which contains them; as a consequence, this CFC will be the relevant binding domain for pronominals, but not for anaphors, because there is no potential indexing whereby they could possibly satisfy the Binding Theory (more specifically, Principle A of the BT) in such a case. Now, looking for the next CFC higher up, we will necessarily meet another subject, which will c-command the anaphor, thus function as a potential binder for it, and therefore turn this larger CFC into a proper CG for it (whether it also contains another potential binder or not). Leaving aside the case illustrated in footnote 2 supra, we may therefore derive the following definition for a GC:

(5) The GC for a pronoun $\alpha$ is the minimal CFC which contains $\alpha$, its governor, and a subject $\beta$ (which c-commands $\alpha$ if $\alpha$ is an anaphor and $\alpha$ is a subject or is contained in a subject $\left.\mathrm{NP}^{3}\right)$.

Admittedly, (5) is not exactly Chomsky's definition, nor is it Huang or Aoun's, which reads like this (Huang (1983: (14)):

(6) $\alpha$ is a governing category for $\beta$ if and only if $\alpha$ is the minimal category containing $\beta$, a governor of $\beta$, and a SUBJECT that, if $\beta$ is an anaphor, is accessible to $\beta$.

In particular, there are divergences concerning the questions (a) whether recourse is to be had to a subject, a SUBJECT, or an accessible SUBJECT, and (b) how to define those SUBJECTs. Those problems need not disturb us though, since this type of approach is clearly insufficient, as will be shown now.

2. Some problems for the minimally relativized locality approach.

2.1. In spite of those differences, then, the empirical content of Chomsky's BT compatibility theory and of the Huang-Aoun theory is similar in most contexts. In particular, both theories are falsified in three cases:

(a) when an anaphor is long distance bound, as are Japanese zibun (Saito \& Hoji (1983), Sportiche (1986), Katada (1988), etc.), Icelandic sig (Maling (1984)), or even Chinese ziji (Tang (1989));

(b) when a pronominal must be free in a wider domain than the minimal CFC or cyclic category which contains it;

(c) when an anaphor must be bound in a narrower domain than the one defined in (5) or (6) - roughly, in the very GC that supposedly holds for (English-like) pronominals.

Chomsky's approach can be maintained in the first case modulo the intervention of an auxiliary theory - the theory of anaphor-movement at LF — and it seems possible to use it to salvage Huang's and Aoun's theories as well (for a typology of anaphors which sometimes move to Infl and sometimes do not, see Katada $(1988 \mathrm{a}, \mathrm{b}))$. In the second case, however, the situation is more difficult: what is needed is a partition of pronominals into two subclasses, ' $U$ pronominals' (unmarked pronominals), which must be free in a domain defined as in (5) or (6), and 'M-pronominals' (marked ones), which must be free in a wider domain. Likewise, to account for the third case, we should also acknowledge the existence of highly marked anaphors, the 
existence of which will be demonstrated in sections 4 and 5. Now if the ability for a pronoun (be it an anaphor or a pronominal) to move to Infl or not may be encoded by a lexical feature, it should be clear that this feature is only a descriptive device really; I hope the investigation of the locality requirements to be done here will therefore help develop the empirical content of such a feature.

For the time being, let us consider the properties of the widely attested M-pronominals. They are typically genitives or possessives, i.e. pronominals which act as subjects of NPs. Consider for instance the opposition between Norwegian sin and hans, Czech svého and jeho, Persian -xod and $-u$, and, outside the Indo-European domain, Basque bere and haren (I give quite a few examples so as to make it clear that this phenomenon is widely attested the world over, although Enç's (1989) new classification of pronouns does not seem to predict their existence):

(7) a. Jon $_{\mathrm{i}}$ beundrer $\sin _{\mathrm{i} / *_{\mathrm{j}}} /$ hans $*_{\mathrm{i}}$ mor (Hellan (1988: 103 (9b))

Jon admires $\mathrm{his}_{\mathrm{i} / \mathrm{j}}$ mother

b. pro $_{\mathrm{i}}$ vide\& l svého $\mathrm{i}_{\mathrm{i} / \mathrm{j}} / \mathrm{j}_{\mathrm{jeho}} *_{\mathrm{i}}$ souseda $(\mathrm{Czech})$ saw his $\mathrm{s}_{\mathrm{i} / \mathrm{j}} \quad$ neighbour

'He saw his neighbour'

(8) a. Ali sag-e-xod-ra@ gardes \& bord (Persian) ${ }^{4}$ Ali dog-e-xod-ACC go made

' $\mathrm{Ali}_{\mathrm{i}}$ walked his $\mathrm{i}_{\mathrm{i}} / *_{\mathrm{j}}$ dog'

b. Ali sag-e-u-rae gardes \& bord

Ali dog-e-u- ACC go made

'Ali $i_{\mathrm{i}}$ walked his $*_{\mathrm{i} / \mathrm{j}}$ dog'

c. Ali sag-es\&-ra@ gardes\& bord

Ali dog-es\&-ACC go made

'Ali i walked his $_{\mathrm{i} / \mathrm{j}}$ dog'

(9) Jonek $_{\mathrm{i}} \quad$ bere $_{\mathrm{i} / *_{\mathrm{j}}} /$ haren $_{*_{\mathrm{i}}}$ liburua irakurri du

Jon-ERG $b$. hook-ABS read AUX

'Jon has read his $\mathrm{i}_{\mathrm{j} j}$ book'

2.2. Crucially, the constraint that the pronominals hans, jeho, -xod and haren be free (here) in the minimal tensed clause which contains them is reminiscent of the locality constraint which governs the distribution of the anaphoric possessives - and, more generally, the distribution of anaphors as predicted by (5) or (6). As a consequence, it seems to be necessary to define various governing categories independently of the anaphoric or pronominal nature of the pronoun considered (more evidence will be given below). Now this is partially what Manzini \& Wexler (1987) set out to do when they proposed the following hierarchy of domains and subdomains (their (29)):

(10) $\gamma$ is the governing category for $\alpha$ iff

$\gamma$ is the minimal category that contains $\alpha$ and a governor for $\alpha$ and

a. $\quad$ can have a subject or, for $\alpha$ anaphoric, has a subject $\beta, \beta \neq \alpha$; or

b. has an Infl; or

c. has a Tns, or

d. has an "referential" Tense; or

e. has a "root" Tense;

if, for $\alpha$ anaphoric, the subject $\beta^{\prime}, \beta^{\prime} \neq \alpha$, of $\gamma$, and of every category dominating $\alpha$ and not $\gamma$, is accessible to $\alpha$. 
The hierarchy (10) was associated with two more parameters: the Lexical Parametrization Hypothesis or LPH (11) [their (37)], and the definition of a proper antecedent (13), linked to the reformulation of the Principles A and B of the binding theory as in (12):

(11) $L P H$ : Values of a Parameter are associated not with particular grammars but with particular lexical items.

(12) A. An anaphor is bound in its GC by a proper antecedent.

B. A pronominal is free in its GC from all proper antecedents.

(13) A proper antecedent for $\alpha$ is:

a. a subject $\beta$; or

b. any element $\beta$.

2.3. The remaining part of this section will be devoted to an evaluation of Manzini \& Wexler's theory.

2.3.1. It can easily be shown that (13) should have more than two values. Thus, in northern Basque, the "proper" binder of the "reflexive" possessive bere introduced in (9) must be a subject, a direct object, or an indirect object, but not an NP corresponding to what a Relational Grammarian would call an Oblique Object or non-term:

(14) a. Peiok Mayi bere amari erakutsi / aipatu dio Peio-ERG Mayi-ABS $b$. mother-DAT shown mentioned AUX 'Peio ${ }_{\mathrm{i}}$ has shown / mentioned Mayi $\mathrm{j}_{\mathrm{j}}$ to $\mathrm{his}_{\mathrm{i} / *_{\mathrm{k}}} /$ her $_{\mathrm{j} / *_{\mathrm{k}}}$ mother'

b. Peio Mayiri bere amaz mintzatu zaio P.-ERG M.-DAT $b$. mother-INS spoken AUX 'Peio ${ }_{\mathrm{i}}$ has talked to Mayi $\mathrm{about}_{\mathrm{j}} \mathrm{his}_{\mathrm{i} /{ }^{*} \mathrm{k}} /$ her $_{\mathrm{j} /{ }^{*} \mathrm{k}}$ mother'

(15) a. Peio Mayirekin bere amaz mintzatu da P.-ABS M.-SOC $b$. mother-INS spoken AUX lit. 'Peio ${ }_{\mathrm{i}}$ has talked with Mayi $_{\mathrm{j}}$ about $\mathrm{his}_{\mathrm{i} /{ }_{\mathrm{k}}} / *$ her mother'

b. Peio Mayiz bere amari mintzatu zaio P.-ABS M.-INS $b$. mother-DAT spoken AUX 'Peio ${ }_{\mathrm{i}}$ has talked about Mayi $\mathrm{j}_{\mathrm{j}}$ to his $\mathrm{i}_{\mathrm{i} / \mathrm{k}} /$ *her mother'

$(14 a, b)$ show that the antecedent of bere may be in the ergative, absolutive, or dative case; however, if one substitutes the so-called sociative case for the dative, as in (15a) vs. (14b), the relevant NP may no longer function as a "proper antecedent" for bere ; likewise, an instrumental NP is not a "proper antecedent" either, as shown in (15b). Consequently, (13) should be replaced by (16) - or perhaps by (17): although I have as yet no empirical evidence for (17b), I do not see why such an option should be forbidden.

(16) A revised definition for proper antecedents.

A proper antecedent for a pronoun $\alpha$ is
a. a subject $\beta$; or
b. a term $\beta$; or
c. any element $\beta$

(17) A further (tentative) revision of the definition of proper antecedents: 
A proper antecedent for a pronoun $\alpha$ is
a. a subject $\beta$; or
b. a nuclear term $\beta$ [= a subject or a direct object $]$; or
c. a term $\beta$; or
d. any element $\beta .5$

2.3.2. The Lexical Parametrization Hypothesis, on the other hand, can only be confirmed. A first corroboration is given by the Persian examples $(8 b, c)$, since the two pronominal suffixes, $(-e)-u$ et -es\& have two distinct GCs, the latter satisfying the minimally relativized definition of locality, and the former requiring the extension whose necessity was argued for above. Note also, in passing, that such a pair of elements clearly argues against any "functional" approach to binding, since given the existence of $-e s \&,(-e)-u$ should not exist, and vice versa!

Turning to Basque, there are at least two distinct illustrations of the necessity of positing the LPH. The first one is provided by the different distribution of the two reciprocal expressions elkar (which is synchronically unanalyzable) and bata bertzea. ${ }^{6}$ lit. 'the one the other'. These expressions sometimes freely alternate, as in (18):

(18) a. Haiek elkarri $_{i}$ / bata bertzeari ${ }_{i}$ liburuak eman dizkiote they-E e.-D batab.-D books-A given AUX

'They have given e.o. books'

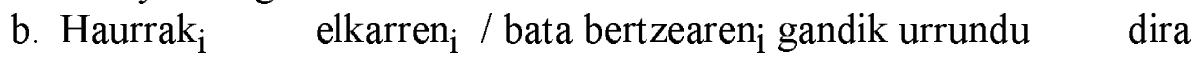
children-the-A e.-G batab.-G from moved-away they-are 'The children have drifted away (form e.o.)'

c. Zuek $\mathrm{gu}_{\mathrm{i}}$ elkarren $_{\mathrm{i}} /$ bata bertzearen $_{\mathrm{i}}$ gandik berexi ga-it-u-zue you-E we-A e.-G batab.-G from parted you-have-us 'You have separated us (from e.o.)'

However, in the following examples, they do not:

(19) a. Guk elkar $_{i}$ ikusi dugu we-E $e_{\text {. }}$ A seen we-have(-it)

'We $\mathrm{e}_{\mathrm{i}}$ have seen each other ${ }_{\mathrm{i}}$ '

b. ${ }^{*} \mathrm{Guk}_{\mathrm{i}}$ bata bertzea $\mathrm{ikusi}_{\mathrm{i}}$ dugu we-E batab.-A seen we-have-it

(20) a. Haiek sugeak $_{\mathrm{j}}$ elkarren ${ }_{*} / \mathrm{j}$ ondoan ikusi dituzte they-E snakes-A e.-G by-the-side seen AUX ' They $_{\mathrm{i}}$ have seen snakes $\mathrm{j}_{\mathrm{j}}$ near each other $*_{\mathrm{i} / \mathrm{j}}$ '

b. Haiek sugeak $_{j}$ bata bertzearen b/??j $_{\text {j }}$ ondoan ikusi dituzte they-E snakes-A batab.-G by-the-side seen AUX ' They $_{i}$ have seen snakes ${ }_{j}$ near each other ${ }_{i, ? ? j}$ '

(21) a. [Peiok eta Mirenek $]_{\mathrm{i}}$ bata bertzearen ${ }_{\mathrm{i}} /$ elkarren $_{\mathrm{i}}$ liburuak irakurri dituzte them P.-E and M.-E batab.-G e.-G books-A read they-have-

'Peio and Miren have read each other's books'

b. [Peio eta Miren $]_{\mathrm{i}}$ elkarren ${ }_{\mathrm{i}} /$ ?? ?bata bertzearen $_{\mathrm{i}}$ lagunak dira P.-A and M.-A e.-G batab.-G friends they-are

'Peio and Miren are mutual friends'

To summarize those primary data, we therefore note that bata bertzea cannot function as 
a direct object, $\mathrm{cf}$ ( $(19 \mathrm{~b})^{7}$; furthermore, the domain in which the two reciprocal expressions can or must find an antecedent is not exactly the same one, see (20); finally, when the genitive pronoun denotes the subject of an NP, elkarren is excluded in most cases, as in (21a), although some contexts, such as (21b) license it - but then, it is the other reciprocal expression which is bad. (Of course, I will return later on to a possible explanation of this difference.)

2.3.3. The second pair of items which do not have the same distribution consists of bere, an inherent genitive, already illustrated in (8) above, and the genitive form bere buruaren of the typical reflexive nominal expression bere burua, lit. 'his own head'. Note in particular:

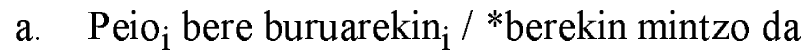

P.-A $b$. head-with $b$.-with talking he-is

'Peio is talking to [lit. with] himself'

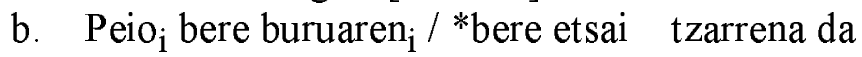

P.-A $b$. head-G. $b$. enemy worst he-is

'Peio is his (own) worst enemy'

(23) Heiek sugeak $_{\mathrm{j}}$ beren $_{\mathrm{i} / *_{\mathrm{j}}} /$ beren buruaren $_{* \mathrm{i} / \mathrm{j}}$ ondoan ikusi dituzte

They snakes $b$. $b$. head-G side-on seen AUX

'They have seen snakes near them(selves)'

(See section 5 for an analysis; when the antecedent is plural, bere becomesberen, but its final $-n$ disappears in front of certain (postpositional) suffixes such as -kin 'with', as in (22a).)

2.3.4. Another, more theoretical, problem with the Manzini-Wexler approach concerns (10a), because the condition that the subject $\beta$ be distinct from the pronoun $\alpha$ only holds (according to the authors) if $\alpha$ is an anaphor. Thus in examples like (2) or (3) above, whose type must have influenced them, the NP that contains the pronominals has a subject (the possessive or genitive pronominal itself), and therefore qualifies as a (narrow) binding domain. But it is not possible, on their hypothesis, to account for the new cases of complementary distribution, exemplified by (7), $(8 \mathrm{a}, \mathrm{b})$ and (9): sin, bere and the like have their GC defined as in (10a), whereas hans, haren and so on have theirs defined as in (10b). In other words, such anaphors and pronominals would not really be in complementary distribution. That thesis should be argued for, but I cannot see any evidence in favour of it.

Admittedly, there are, in Basque, two types of constructions in which bere and haren are not in complementary distribution. They are illustrated by (24):
a. $\quad$ Peio $_{\mathrm{i}}$ berekin $_{*_{\mathrm{i}} / *_{\mathrm{j}}} /$ harekin $_{*_{\mathrm{i} / \mathrm{j}}}$ mintzo da [compare $(22 \mathrm{a})$ ]
P.-ABS $b$.- with $h$.-with talking he-is
b. Peiok Mireni $_{\mathrm{j}}\left[\mathrm{PRO}_{\mathrm{j}}\right.$ haren $_{\mathrm{i} / *_{\mathrm{j}} / \mathrm{k}} /$ bere $_{*_{\mathrm{i}} / *_{\mathrm{j}} / *_{\mathrm{k}}}$ ikusteko] erran dio
P.-ERG Miren-DAT $h$. b. to-see said AUX
'Peio has told Miren to see him/herself'

Here, bere is altogether out in both cases, whether its referential index is $i$ or $j$ (or $k$ ), i.e neither bere nor haren will do in (24a) with index $i$ or in (24b) — where the "nominalized" character of the embedded clause allows the direct object NP to be in the genitive - with index $j$ (again, bere buruaren would be fine here, at least with index $j$ ). We shall see below what kind of hypothesis should account for these data: the ungrammaticality of bere here is clearly linked to the distributional differences between bere and bere burua(ren); on the other hand, there is no evidence whatsoever in favour of the prediction made by Manzini \& Wexler's hierarchy that a systematic distinction should be made between the definition of the GC for anaphors, which 
should include the presence of a distinct subject 8 , and the definition of the GC for "longdistance" pronominals, which would be characterized by the presence of an Infl element ${ }^{9}$.

\section{The Bounding Condition and its Consequences for the BT.}

3.1. The various revised binding theories examined so far have one common feature: they all postulate that the GC for anaphors is either as large as, or larger than, the GC for pronominals. That is obvious in Chomsky's formulation of BT compatibility, but also in the Huang-Aoun proposal (6), and in the qualification concerning anaphors in Manzini \& Wexler's hierarchy (10). Note moreover that, as was explained above, the three approaches somehow always associate anaphors with subjects (or SUBJECTs).

Up to now, I have only shown that some pronominals have wider GCs than expected indeed, that such entities (dubbed "M-pronominals") must be free exactly in the domain which qualifies as a GC for unmarked (i.e. not long-distance bound) anaphors. However, I have not shown yet that there are anaphors which must be bound in a domain that is narrower than the one recognized for those unmarked anaphors (they would correspond to case (c) in section 2.1). If such entities existed, we would have a much stronger argument in favour of of M\&W's LPH (11), because there would no longer be any connection between a pronoun's type and a Governing Category's size; in particular, there would no longer be any necessary connection between a pronoun's being an anaphor and the presence of a subject or SUBJECT in its GC.

Before we give some empirical evidence in favour of such a point of view, let us give a quick glance at a theory which already has the required properties, and consequently makes the prediction that some anaphors do exist whose GC corresponds to the narrow domain which Huang, Chomsky and others thought was only fit for (U-)pronominals - namely, Koster's (1987) drastic revision of Manzini \& Wexler's theory. According to him, then, the minimal GC or binding domain is defined by the Bounding Condition (25) (op. cit.: 10 (23)), and must therefore be defined independently of any reference to a subject, as in the (a) option of (26) [his (11), p. 321]:

(25) A dependent element $\delta$ cannot be free in:

$[\beta \ldots \delta \ldots] \ldots$

where $\beta$ is the minimal $\mathrm{X}^{\mathrm{max}}$ containing $\delta$ (and the governor of $\delta$ )

(26) $\gamma$ is a GC for $\alpha$ iff

$\gamma$ is the minimal $\mathrm{X}^{\mathrm{max}}$ which contains $\alpha$ and

a. has the governor of $\alpha$

and

b. has a subject, or

c. has an Infl, or

d. has a Tns, or

e. has an indicative Tns, or

f. has a root Tns

Crucially, as was said above, we should expect to discover anaphors that must be bound in a domain which is smaller than Aoun's or Chomsky's GC for anaphors. Koster illustrates this with the following French data (320: (9), (10)):
a. *Il parle de se
he talks of se
b. Il se lave
he $s e$ washes 


\section{'He washes (himself)' \\ c. Il parle [PP de lui-même] \\ he talks of himself \\ 'He talks about himself'}

According to Koster, the ungrammaticality of (27a) illustrates the fact that se must be bound in the smallest possible domain - i.e. the one defined by the bounding condition (25), without any extension whatsoever: if one included the presence of a subject (or SUBJECT) in the definition of the GC for se , (27a) should be grammatical. Or should it? Things are not so clear though, because there is yet another ungrammatical sentence that ought to be taken care of:

$$
\text { *Il lave se [compare (27b)] }
$$

If the ungrammaticality of (28) is explained away (as it would in traditional terms) by recourse to the fact that se is a clitic, I can see of no reason why the same reasoning could not carry over to (27a). Furthermore, there is some evidence that se may well not be, after all, an anaphor; note in particular that se verbs behave like intransitive verbs, rather than transitive ones, in factitive constructions (a fact already alluded to in Kayne (1975)):
(29) a. Il le lave
he it washes
'He washes it'
b. Je le lui fait laver
'I make him wash it'
c. *Je lui fait le laver
a. Il dort
he sleeps
'He is asleep'
b. Je le fais dormir
I him make sleep
'I put him asleep'

(31) a. Il se lave $[=(27 b)]$

b. Je le fais se laver [compare (30b)]

I him make se wash

c. *Je le se fais laver / *Je se le fais laver [compare (29b)]

Koster's evidence is, consequently, rather shaky. Moreover, his treatment of Dutch zich is also open to criticism ${ }^{10}$. However, it is my contention that Koster's theory is basically right, and I will now endeavour to defend it by analyzing some of the Basque examples tintroduced above. A few modifications and qualifications to this model will of course be introduced.

\section{The Two Reciprocal Expressions in Basque.}

4.1. Let us first consider more closely the cases in which the reciprocal pronouns elkar andbata bertzea are not in complementary distribution, viz. (19)-(21), repeated here.

(19) a. Guk elkar $_{i}$ ikusi dugu

we-E $e$.-A seen we-have(-it)

' $W e_{i}$ have seen each other' ${ }_{i}$ 
b. ${ }^{*} \mathrm{Guk}_{\mathrm{i}}$ bata bertzea $\mathrm{ikusi}$ dugu

we-E batab.-A seen we-have-it

(20) a. Haiek sugeak $_{\mathrm{j}}$ elkarren ${ }_{\mathrm{i} / \mathrm{j}}$ ondoan ikusi dituzte they-E snakes-A e.-G by-the-side seen AUX

'They ${ }_{\mathrm{i}}$ have seen snakes $\mathrm{j}_{\mathrm{j}}$ near each other ${ }_{*_{\mathrm{i}} \mathrm{j}}$ '

b. Haiek sugeak $_{\mathrm{j}}$ bata bertzearen $\mathrm{i}_{\mathrm{i} / ? \mathrm{j}}$ ondoan ikusi dituzte they-E snakes-A batab.-G by-the-side seen AUX

'They ${ }_{\mathrm{i}}$ have seen snakes $\mathrm{j}_{\mathrm{j}}$ near each other $\mathrm{i}_{\mathrm{i} / \text { ??j }}$ '

(21) a. [Peiok eta Mirenek $]_{\mathrm{i}}$ bata bertzearen ${ }_{\mathrm{i}} /$ eelkarren $_{\mathrm{i}}$ liburuak irakurri dituzte

P.-E and M.-E batab.-G e.-G books-A read they-have-them

'Peio and Miren have read each other's books'

b. [Peio eta Miren $]_{\mathrm{i}}$ elkarren $_{\mathrm{i}} /$ ??bata bertzearen $_{\mathrm{i}}$ lagunak dira

P.-A and M.-A e.-G batab.-G friends they-are

'Peio and Miren are mutual friends'

Intuitively, what the sentences in (20) show is that whereas elkar must be bound by an antecedent which is, in a sense to be made more precise, "very close" to it, bata bertzea, on the other hand, may not be bound by an NP which is "too close". From this point of view, we may infer that the subject NP in (19) is close enough for elkar, but too close for bata bertzea . Conversely, in (21a), the only possible binder for these items - the subject NP again - is too far away from elkar(ren), but not too close for bata bertzea(ren). It follows that the notion of subject (or SUBJECT) is clearly irrelevant if we want to characterize this notion of "closeness" more specifically. We are therefore entitled, and even forced, to adopt Koster's position, according to which the smallest GC of a pronoun $\delta$ is, as its very name indicates, purely defined in terms of the presence of $\delta$ and its governor.

Assuming with Koster that the minimal $\mathrm{X}^{\mathrm{max}}$ which corresponds to a verb as a governor for a pronoun is the full clause which contains this verb (rather than the VP itself), we may propose the following generalizations for the two Basque reciprocal expressions:

(32) a. The reciprocal expression elkar must be bound in the minimal GC [as defined by (26a)].

b. The reciprocal expression bata bertzea must be

(i) free in the minimal GC, and

(ii) bound in the immediately wider domain defined by (26b).

It follows that elkar is correctly bound in its minimal $\mathrm{X}^{\max }$ in (19a), i.e. the whole independent clause, in spite of the fact that no reference is made to the presence of a subject in the definition of that $X^{\max }$. On the other hand, in (19b), although bata bertzea is likewise correctly bound in the same clause, as required by (32bii), it is at the same time incorrectly bound in this self-same domain, due to the fact that the category defined by (32bi) happens, in this particular case, to be identical to the other one ${ }^{11}$. Incidentally, note that this approach, which relies on the fact that the VP is somehow transparent for binding, could unproblematically be replaced by the (more and more widely shared) hypothesis that a subject NP originates within the VP: the subject's trace would correctly bind elkar of (19a) within the Vmax proper, and the ungrammaticality of (19b) would now be derived not from the coindexation of bata bertzea and the s-structure subject NP, but rather from its coindexation with the subject's trace, as in (33).

(33) $\mathrm{Guk}_{\mathrm{i}}\left[\mathrm{vP}_{\mathrm{i}} \mathrm{t}_{\mathrm{i}}\left[\mathrm{V}^{\prime}\right.\right.$ elkar $\mathrm{r}_{\mathrm{i}}$ * *bata bertzea ikusi $]$ dugu we-E $e$ batab.-A. seen we-have(-it) 
'We $\mathrm{i}_{\mathrm{i}}$ have seen each other'

In (21a) now, the minimal $\mathrm{X}^{\max }$ in which elkar must be bound, and bata bertzea, free, is obviously the NP which contains them; as a consequence, the lexical properties specified in (32), in so far as they are associated with (some variant of) Koster's theory, correctly explain the behaviour of the two reciprocal expressions.

4.2. Let us turn to the examples (20). The $X^{\max }$ in which elkar must be bound and in which bata bertzea must be free is, according to Koster, the PP which contains them, since, by definition, this PP contains their governor (the head ondoan 'near') ${ }^{12}$. Now, given (32a), elkar should be out in (20a), although it is not, at least on one interpretation. Moreover, in (20b), the indexing $j$ on bata bertzea should be good, contrary to the facts. A priori, there are (at least) three possible solutions to the problem raised by elkar.

4.2.1. First, we could imagine that (32a) should be modified so as to allow elkar to look for a binder in the next $\mathrm{X}^{\mathrm{max}}$ up if there is no potential binder for it in its minimal $\mathrm{X}^{\mathrm{max}}$. This solution, however, is untenable. Firstly, since the object NP can bind elkar, but the subject NP cannot, we would have to say that the next $\mathrm{X}^{\mathrm{max}}$ up above the PP is the VP, a stipulation which would directly contradict Koster's assumption, that the minimal $\mathrm{X}^{\max }$ which corresponds to a verb as a governor is the minimal full clause which contains them; note that this objection is still valid if we adopt a representation like (33), since the subject's trace will still illegally bindelkar. Secondly, and perhaps more decisively, this approach would be inconsistent with the description of bata bertzea(ren) 's behaviour, since the same object NP sugeak cannot bind it here: the requirement (32bi) that bata bertzea(ren) be free in its minimal $\mathrm{X}^{\max }$ would have to be totally modified. This first approach must therefore be given up.

4.2.2. A second solution would be to postulate, contrary to Koster's opinion, that locative PPs do contain a c-commanding NP which could act as a potential binder for elkar and as a contrabinder for bata bertzea : after all, the prepositional or postpositional complement NP localizes another item (be that an NP, a VP, or a clause) - i.e. such Ps are lexically bivalent or dyadic, just as transitive verbs are. Now what would the nature of this argument be? Let us assume it is a $\mathrm{PRO}^{13}$ : admittedly, this PRO is governed (by the $\mathrm{P}$, which assigns it the Theme rôle), but it has sufficiently been demonstrated that obligatorily controlled PROs are governed, as opposed to arbitrary PROs (see Mohanan (1985), Kiss (1987), Koster (1987), Sigurfsson (1990) etc.). The correct representation of the PP under scrutiny would then be as in (34a), (34b) representing the wole sentences of (20):

$$
\begin{aligned}
& \text { a. }\left[\mathrm{PP} \mathrm{PRO}_{\mathrm{k}}\left[\mathrm{P}^{\prime}\left[\mathrm{NP} \text { elkarren }_{\mathrm{k}} / \text { bata bertzearen }_{? ? \mathrm{k}}\right] \text { [P ondoan] }\right]\right] \\
& \text { e.-G batab.-G by-the-side } \\
& \text { b. Haiek }{ }_{\mathrm{i}}\left[\mathrm{VP}_{\mathrm{i}} \mathrm{t}_{\mathrm{V}} \mathrm{Sugeak}_{\mathrm{j}}\left[\mathrm{PRO}_{\mathrm{k}} \text { elkarren }_{*_{\mathrm{i} / \mathrm{k}}} / \text { bata bertzearen }_{\mathrm{i} / \text { ??k }} \text { ondoan }\right]\right. \text { ikusi]] } \\
& \text { they-E snakes-A e.-G batab.-G by-the-side seen } \\
& \text { dituzte } \\
& \text { AUX } \\
& \text { 'They have seen snakes near each other' }
\end{aligned}
$$

The indexation of $(20 \mathrm{a}, \mathrm{b})$ would then be derived from a theory ensuring that $j=k$, i.e. that the controller of the PRO element is, and may only be, the object NP sugeak.

I would now like to suggest that such a theory could be derived from the interaction of the binding theory itself, and of the theory of predication. In the unmarked case, non arbitrary PROs are pronominal anaphors: they must be free in the minimal domain defined by (26a), and bound in the next domain up which contains a distinct or c-commanding subject. (The question of the 
designated controller need not bother us here, since the PRO under discussion is not the subject of a complement clause. Note also that the fact that PRO would be governed here no longer entails a contradiction with respect to the Binding Theory, since it may well - indeed, must be free in a domain smaller than the one in which it must be bound.) Besides, we know independently that a predicative relation obtains when an NP and an adjacent XP are sisters: the $\mathrm{XP}$ is the predicate, and, logically, the NP is the subject of the predication. It follows that in a $\mathrm{V}^{\prime}$ which contains a direct object NP and a PP, a clause-like entity is created, as in (35), where the angled brackets indicate the predication in question ${ }^{14}$ and where the position of the $\mathrm{V}$ head is of course irrelevant:

\section{(35) $\left[\mathrm{VP} \ldots\left[\mathrm{V}^{\prime}, \mathrm{V}<\mathrm{NP}\right.\right.$ PP $\left.\left.>\right]\right]$}

Assume now that a subject of predication (henceforth SP), being the subject closest to the PRO within the PP, necessarily controls it. The indexation of (34b) may now be directly read off the following structure:

(36) $\left[\mathrm{VP}_{\mathrm{i}} \mathrm{t}_{\mathrm{V}}{ }^{\prime}<\operatorname{sugeak}_{\mathrm{j}}\left[\mathrm{PP} \mathrm{PRO}_{\mathrm{j}}\left[\mathrm{P}^{\prime}\right.\right.\right.$ elkarren $_{*_{\mathrm{i} / \mathrm{j}}} /$ bata bertzearen $_{\mathrm{i} / \text { ??j }}$ ondoan $\left.\left.\left.]\right]>\mathrm{ikusi}\right]\right]$ dituzte

4.2.3. The third solution is directly connected with the preceding one, the idea being that perhaps we could do without a PRO in the PPs, given the fact that SPs somehow seem always to induce a (possibly abstract) binding domain (recall that the initial trace in (36) may not bind elkarren ). In other words, are not pre- or postpositional subject PROs redundant, once the necessity of the existence, or the operativeness, of SPs has been demonstrated? In a sense, they seem to be: given the predication relation that holds between the NP sugeak and the PP to its right, we now are able to state directly that the NP sugeak induces a binding domain which excludes the sentential subject's trace, and within which elkarren must be bound, and bata bertzearen must be free.

4.3. However, several objections can be made against this tentative reduction (even if we leave aside the most obvious one, which is that if the secondary predication represented by the angled brackets in (35-36) does not form a constituent - as would a Small Clause - , then there is no clear sense in which the notion "binding domain" could be defined). Consider first the indexation in (18), or in a variant like (37):

$$
\begin{aligned}
& \text { Guk }_{\mathrm{i}} \text { neskak }_{\mathrm{j}} \text { elkarri }_{\mathrm{i} / \mathrm{j}} / \text { bata bertzeari } \mathrm{i}_{\mathrm{i} / \mathrm{j}} \text { erakutsi dizkiogu } \\
& \text { we-E girls-A } \text { e. -D } \text { batab.-D Dhown AUX } \\
& \text { 'We have shown the girls to each other' }
\end{aligned}
$$

Here, contrary to the situation which obtains in the "snake" sentences, elkar may be bound either to the object NP (a most unlikely interpretation in (18a), given the content of its object NP, but clearly good in (37)), or to the subject NP. Now what is noteworthy is that the object $\mathrm{NP}$ is not localized with respect to elkar. We may therefore conclude that there is no predication involved here, at least in the relevant sense, and in spite of the strict sisterhood condition which may well be respected in the context. Moreover, the dative NP is subcategorized for by the verb. It follows that the smallest $\mathrm{X}^{\max }$ which contains elkar(ri) is, in Koster's terms, the clause, or, in more recent terms, the VP, inasmuch as it contains a trace of the subject NP (cf.(33) etc.); in either case, there are two NPs which c-command elkar, and since both of them are compatible with it in number, both can bind it, as the indexation in (37) shows.

But dative NPs have another interesting property in the northern dialects studied here: they may, or just as well may not, be cross-referenced in the inflected verb; as a consequence, the dative suffix may be viewed either as a real case ending (which will "trigger" agreement or be 
licensed by it) or as a postposition (which of course will neither trigger agreement nor be licensed by it). In the latter case, since there still is no localization involved, there may of course be no PRO inside the dative PP (a point to which I return); hence the possibility for the other reciprocal expression, bata bertzeari, to be able to refer, like elkarri, either to the subject NP or, more surprisingly in the present case, to the object NP: given the absence of a PRO within the "dative PP", bata bertzea is correctly free in it, and correctly bound in the next category up, i.e. the VP which contains the subject trace, or the full clause - in either case, (32b) is respected, the operativeness of the definition (26a) is once more vindicated, and, finally, the contrast between (18) or (37) and the snake sentences seems best explained in terms of the presence of a PRO in the PPs of the latter.

Let us now turn to $(18 \mathrm{c})$, repeated here:

$$
\begin{aligned}
& \text { c. Zuek } \mathrm{gu}_{\mathrm{i}} \text { elkarren } / \text { / bata bertzearen }{ }_{\mathrm{i}} \text { gandik berexi ga-it-u-zue } \\
& \text { you-E we-A e.-G batab.-G from parted you-have-us } \\
& \text { 'You have separated us (from e.o.)' }
\end{aligned}
$$

Again, elkar and bata bertzea freely alternate. Note in particular that in this example, where the $\mathrm{P}$ is not stative, but dynamic (it is in the ablative case), the second reciprocal expression may be coindexed with the sentential object. How are we to account for this state of affairs? One possible answer is to say that dynamic or non-stative locative PPs have no PRO subjects; it ensues that bata bertzea would correctly be free in the minimal $\mathrm{X}^{\mathrm{max}}$ which contains its governor, the PP headed by gandik (note that, just as in the preceding paragraphs, such a stipulation would eventually indirectly corroborate the hypothesis that stative locative PPs do have such PROs, and, more generally, Koster hypothesis that the canonical GC is as defined in $(26 a))^{15}$

One might object, however, that such an approach is highly counter-intuitive: how could the stative vs. dynamic status of a PP determine the presence vs. absence of a PRO inside it? The solution to this problem, although indirect, might be sought in the following direction: perhaps the establishment of a (secondary) predicative relation really requires that the (secondary) predicate be stative; thus the PRO within a PP would be licensed only when it was actually controlled, and bound, by an SP: if there is no (stative) secondary predication, there is no controller for the PRO, so that the PP with a PRO in its SPEC position would be ruled out ${ }^{16}$.

4.4. Before I summarize the tentative solutions proposed in the foregoing paragraphs, I must also address the question raised by the opposition between (21a) and (21b). As we saw earlier, the first example is unproblematic, at least if we stick to (32a) and add no default clause to it: since there is no possible binder for elkar within the minimal $\mathrm{X}^{\max }$ which contains it and its governor, i.e. the NP itself, elkar is correctly predicted to be out there, and bata bertzea to be in.

Clearly, this solution does not directly carry over to (21b), since the reverse judgements obtain there. But, as we noted before, the head noun in $(21 \mathrm{~b})$ is dyadic, so that we can consider the genitive pronoun to denote the object of the semantic relation denoted by the noun; as a result, we may postulate that an invisible subject - a PRO — is once more present ${ }^{17}$; moreover, note that the sentence ( $21 \mathrm{~b}$ ) is a stative predication; consequently, if we keep to the restriction concerning the licensing of PRO suggested above, we see that the PRO element is licit here, and bound by the sentential subject (an SP); furthermore, elkar will be bound by that PRO, and bata bertzea will be ruled out because PRO, being bound by the sentential subject, will carry the same referential index as the pronominal anaphor. This analysis seems to be supported by new facts such as the following:

(38) a. Guk $_{\mathrm{i}}<[\text { Jon eta Miren }]_{\mathrm{j}}\left[\mathrm{PRO}_{\mathrm{j}}\right.$ elkarren $*_{\mathrm{i} / \mathrm{j}}$ etsai-tzat/-ak $]>$ dauzkagu we-E J.-A and M.-A e.-G enemy-PROL/-A we-hold-them 
'We $\mathrm{i}_{\mathrm{i}}$ consider [Jon and Miren $]_{\mathrm{j}}$ each other's $*_{\mathrm{i} / \mathrm{j}}$ enemies'

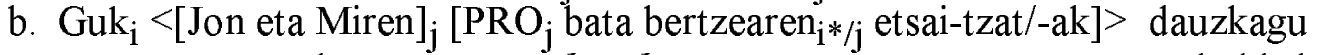
we-E J.-A and M.-A batab.-G enemy-PROL/-A we-hold-them

' $\mathrm{We}_{\mathrm{i}}$ consider [Jon and Miren $]_{\mathrm{j}}$ each other' $\mathrm{s}_{\mathrm{i} / *_{\mathrm{j}}}$ enemies'

(39) a. *Elkarren etsaiak etorri dira

e.-G enemies-A come AUX

'Each other's enemies have come'

b. *Guk elkarren etsaiak ikusi ditugu

we-E e.-G enemies-A seen AUX

'We have seen each other's enemies'

(40) a. *Bata bertzearen etsaiak etorri dira

batab.-G enemies-A come AUX

[cf. (39a)]

b. Guk $_{\mathrm{i}}$ bata bertzearen ${ }_{\mathrm{i}}$ etsaiak ikusi ditugu

we-E batab.-G enemies-A seen AUX

'We have seen each other's enemies'

In (38a), the object NP and the attributive NP constitute a secondary stative predication ; PRO is thus licit, and bound by the complex object NP. In accordance with (32), elkarren is therefore bound by $\mathrm{PRO}_{\mathrm{j}}$, while in (38b), by the same reasoning, bata bertzearen is disjoint from PRO and correctly bound in the GC defined by (26b). Crucially, however, the sentences in (39) are not grammatical. The reason should by now be obvious: the predications are not stative, hence the impossibility for PRO to appear inside the absolutive NP18. Such examples are consequently ruled out just as (21a) with elkarren was. On the other hand, the absence of PRO in the absolutive NP in (40) does not have the same consequences: in (a), bata bertzearen is out although is is correctly free in the domain of its governor: that is because there is no NP to bind it ouside of the NP (see (41b) below). But in (40b), nothing prevents guk from binding bata bertzearen in the extended GC defined in (26b): the sentence is consequently grammatical.

4.5. To summarize, we can say that the various syntactic contexts in which the two reciprocal expressions elkar and bata bertzea are grammatical, although they are not homegeneous, consistently point towards the following analysis:

(41) There are two relevant GCs for the reciprocal expressions $\alpha$ in Basque:

a. the minimal $\mathrm{CG}$, or $\mathrm{CG}_{\emptyset}$, which is the minimal $\mathrm{X}^{\mathrm{max}}$ which contains $\alpha$ and its governor;

b. an extension of $\mathrm{GC}_{\emptyset}, \mathrm{CG}_{1}$, which is the smallest category or $\mathrm{X}^{\mathrm{max}}$ which contains

$\alpha$,its governor, and a SUBJECT which excludes $\alpha^{19}$.

(42) The Basque reciprocal expressions are lexically constrained as follows [cf. (32)]:

a. Elkar must be bound in $\mathrm{GC}_{\emptyset}$.

b. Bata bertzea must be free in $\mathrm{CG}_{\emptyset}$ and bound in $\mathrm{GC}_{1}$

(43) The minimal $X^{\max }$ projections referred to in (41) depend on the lexical nature of the governor of $\alpha$ :

a. If the governor of $\alpha$ is $\mathrm{V}$, then the relevant $\mathrm{X}^{\max }$ is the minimal clause which contains it, or, on the analysis according to which the subject NP originates in the VP, this VP itself.

b. If the governor of $\alpha$ is an $\mathrm{N}$ or a $\mathrm{P}$, then the $\mathrm{X}^{\max }$ is an NP or a PP. 
A more unexpected finding of the foregoing paragraphs, whose rôle is essential in the determination of the indexation of the reciprocal anaphors studied here, can be summed up by the following principles:

(44) a. NPs whose heads are dyadic and locative PPs (can) have a non Case-marked, but governed PRO which will function as a SUBJECT in (41b), provided that:

b. the PRO internal to such NPs and PPs is licensed, i.e. only if the phrase in question is the predicate of a (primary or secondary) stative predication, and this PRO is coindexed with the subject of that predication.

5. 'Bere', 'bere burua' and relateds matters.

5.1.1. The foregoing results are corroborated by the distribution of, and opposition between, the inherent 'reflexive' genitive bere, and the genitive form of the full reflexive expression bere burua, already illustrated in (22) and (23), repeated here with a fuller indexation:

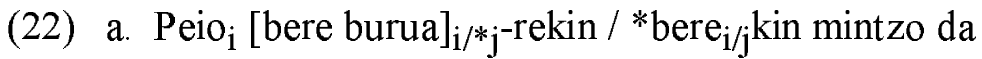

P.-A $b$. head-with b.-with talking he-is

'Peio is talking to [lit. with] himself'

b. Peio ${ }_{\mathrm{i}}[\text { bere buruaren }]_{\mathrm{i} / *_{\mathrm{j}}} / *$ bere $_{\mathrm{i} / \mathrm{j}}$ etsai tzarrena da

P.-A $b$. head-G. $\quad b$. enemy worst he-is

'Peio is his (own) worst enemy'

(23) Heiek $_{\mathrm{i}}$ sugeak $_{\mathrm{j}}$ beren $_{\mathrm{i}{ }_{\mathrm{j}}} /$ [ beren buruaren ${ }_{*_{\mathrm{i}, \mathrm{j}}}$ ondoan ikusi dituzte

They snakes $b$. $b$. head-G side-on seen AUX

'They have seen snakes near them(selves)'

The null hypothesis is that the pair of reflexives reproduces the constraints established for the reciprocals, and these examples confirm this thesis: bere, like bata bertzea, is constrained by (42b), whereas bere burua, like elkar, is constrainedby (42a). It directly follows that these items can only have the indexing given in the examples, since sugeak and the locative PP constitute a stative (secondary) predication in (23). The case of (22b) is just as straightforward: since the full clause is a stative (equative) predication, bere is out, because it cannot help being locally bound by the PRO specifier of its NP, this PRO being in its turn coindexed with the sentential subject; conversely, bere burua is $\mathrm{OK}$, since it is locally bound in its $\mathrm{GC}_{\varnothing}$

Finally, (22a) may seem to be problematic, but this is only because two analyses (or even three) seem to be available.

(a) If -kin is considered (as it traditionally is, and as the spelling indicates) to be a case suffix, the case itself being assigned by the verb, the projection of that $\mathrm{V}$ (whether the full clause or the VP with the subject's trace) is the $\mathrm{GC}_{\varnothing}$ for bere, whence its unacceptability, and the simultaneous grammaticality of bere burua(ren).

(b) Another approach would be to consider -kin a $\mathrm{P}$ which governs the genitive; we therefore have to decide whether this $\mathrm{P}$ is, or at least may sometimes be, dyadic. In the example under discussion, there is no stative predication; hence, a PRO inside the PP cannot be licensed, so that the grammaticality of bere buruaren and the ungrammaticality of berekin in (22a) both follow.

But consider now a sentence like (45a) and its representations $(45 \mathrm{~b}, \mathrm{c})^{20 \text { : }}$

(45) a. Peio bere amarekin dago

P.-A $b$. mother-G-with is/stays 

'Peio ${ }_{\mathrm{i}}$ is (staying) with his $\mathrm{s}_{\mathrm{i} / *_{\mathrm{j}}}$ mother'
b. Peio $_{i}\left[{ }_{V P} t_{i}\left[P P P R O_{i}\left[P^{\prime}\left[\mathrm{NP}_{\text {bere }} \text { ama-re- }\right]_{j}\right.\right.\right.$-kin] $]$ dago $]$
c. Peio $_{i}\left[V_{P} t_{i}\left[P P\left[P^{\prime}\left[N P \text { bere }{ }_{i} \text { ama-re- }\right]_{j}-\right.\right.\right.$ kin $\left.]\right]$ dago $]$

If the $\mathrm{P}-$ kin is bivalent, as in (b), we see that bere is correctly free within its $\mathrm{GC}_{\varnothing}$, the $\mathrm{NP}$, and bound in its $\mathrm{GC}_{1}$, the PP with a PRO; but if -kin is monovalent, we obtain the same results, although more directly — and just as if -kin was a case suffix.

5.1.2. Consider now the fact that for some speakers, (46a) only has the reading (b) ${ }^{21}$, whereas for other speakers, it has the ambiguous interpretation (c).

(46) a. Guk haurrak elkarrekin ikusi ditugu we-E children-A $e$.-with seen we-have-them

b. ' $W e_{i}$ have seen the children together $_{*} /{ }_{j}$ '

c. ' $\mathrm{We}_{\mathrm{i}}$ have seen the children together $_{\mathrm{i} / \mathrm{j}}$ '

It might be thought such data had something to do with a parameter concerning the binding conditions which govern elkar; however, it may well be the case that it is more simply a matter of analyzing -kin either (i) as a monadic postposition, or (ii) as a dyadic one. In the first case, there is a secondary predication, but no PRO; as as consequence, it is the verb projection which is the minimal $\mathrm{X}^{\max }$ within which elkar must be bound: interpretation (c) obtains; in the second case, though, the PRO within the PP is licensed, whence the (b) reading.

5.1.3. Another illustration of the opposition between bere and bere burua is provided by the following variant of $(24 b)$ :

(47) Peiok $_{\mathrm{i}}$ Mireni $_{\mathrm{j}}\left[\mathrm{PRO}_{\mathrm{j}} \text { *bere / [bere buruaren }\right]_{\mathrm{i} / \mathrm{j}}$ ikusteko] erran dio P.-ERG Miren-DAT $b$. b. head to-see said AUX 'Peio has told Miren to see herself/*him'

The complex expression bere burua is the direct object of the embedded verb; thus, it must be bound in its maximal projection, as indicated by the indexing in the example. On the other hand, bere should be free in that projection, since it is submitted to (42b), just as elkar is: it cannot carry the index $j$; however, at the same time, by the second clause of (42b), it should also be bound in the same syntactic domain; it follows that it cannot appear here 22 .

5.2. Up to now, bere and bere burua have been analyzed as unrelated entities, but this was really begging the question whether there was, or was not, a violation of the $*_{\mathrm{i} / \mathrm{i}}$ filter: on the one hand, if we assign the antecedent's index to the complex reflexive expression bere burua, we cannot assign it at the same time to bere ; on the other hand, we know that bere itself must be coindexed with the antecedent, since if we substitute the pronominal haren for it, we obtain a literal reading 'his head', where the possessor (his) must be referentially disjoint from the subject. Could then this paradox be solved by assigning two distinct indexings to a sentence containing bere burua, as in $(48 \mathrm{a}, \mathrm{b})$, a solution possibly enhanced by the obligatoriness of the indexing of $(48 \mathrm{c})$ ?

(48) a. Peiok ${ }_{\mathrm{i}}[\text { bere burua }]_{\mathrm{i}}$ ikusi du

Peio-E $b$. head-A seen he-has(-it)

'Peio has seen himself'

b. Peiok ${ }_{i}\left[\right.$ bere $_{i}$ burua $_{j}$ ikusi du

Peio-E $b$. head-A seen he-has(-it) 
'Peio ${ }_{\mathrm{i}}$ has seen his $\mathrm{i}_{\mathrm{i} / *_{\mathrm{j}}}$ head'

c. Peiok $_{\mathrm{i}}\left[\text { haren } *_{\mathrm{i} / \mathrm{j}} \text { burua }\right]_{\mathrm{k}}$ ikusi du

Peio-E $h$. head-A seen he-has(-it)

'Peio ${ }_{\mathrm{i}}$ has seen his $* \mathrm{i} / \mathrm{j}$ head'

Attractive though it may be at first sight, this approach has several drawbacks to it. First, I know of no ad hoc mechanism whereby a pronoun like bere could lose its being submitted to some kind or version of the Binding Theory ${ }^{23}$. Second, such sentences as (49) below make it clear that from a morpho-syntactic viewpoint, the direct object expression remains crossreferenced in Infl as a 3rd p. entity 24 .

$$
\begin{aligned}
& \mathrm{Nik}_{\mathrm{i}}[\text { ene / neure burua }]_{\mathrm{i}} \text { ikusi dut / *naut } \\
& \text { I-E my head seen I-have(-it) / I-have-me } \\
& \text { 'I have seen myself' }
\end{aligned}
$$

We must therefore conclude that (48a) is not a good representation, even for the intended (global) reflexive reading of the sentence, and that (48b) must somehow of and by itself allow the two interpretations 'himself' and 'his (own) head'.

How could we achieve this? As there is no locality contraint involved, I will only sketch an answer, which will hopefully taken up in greater detail in some future work. The basic idea I wish to put forth is that, in fact, bere burua is an independant NP at s-structure, and, as such, is submitted to the non-coreference rule which underlies both the principles $\mathrm{B}$ and $\mathrm{C}$ of the binding theory. However, the $\mathrm{N}$ buru(a) might actually be marked in the lexicon as [ \pm referential], a feature that plays no role at s-structure, but whose specification will be decisive at the proper level of semantic interpretation, i.e. at LF: if burua is [+referential], then nothing special happens; on the contrary, if it is marked [-referential], then the index of bere will percolate up and land on the NP node itself, thereby replacing the surface index assigned to it at s-structure.

Two consequences may be noted.

(a) There will never be a violation of the $\mathrm{i} / *_{\mathrm{i}}$ filter, since the indexation $\left[\text { bere }_{\mathrm{i}} \text { burua }\right]_{\mathrm{j}}$ respects it at S-S, and also in the case of a literal interpretation at LF; furthermore, if burua is [-referential], the indexing at LF will be [bere burua $]_{\mathrm{i}}$, owing to the percolation mechanism alluded to: the reflexive phrase will somehow function like an idiomatic one, in which sloppy identity always obtains ${ }^{25}$.

(b) The same expression is not subject oriented when it receives a literal interpretation, but it definitely is when it is globally anaphoric, as (50) below shows: the (b) reading is literal, and not subject-oriented (the object Miren can bind bere ), whilst the (c) reading is both non-literal, and subject oriented (the object NP cannot bind the full reflexive expression).

(50) a. Peio $_{i}$ Mireni $_{j}$ bere buruaz mintzatu zaio P.-A Miren-D b. head-INST spoken AUX

b. 'Peio ${ }_{i}$ has talked to Miren $_{j}$ about his $_{i} /$ her $_{j}$ head'

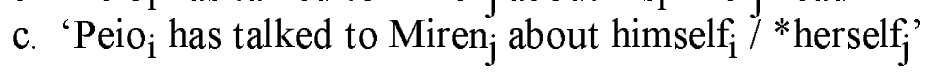

6. Further Questions and Conclusions.

6.1. Let us finally return to (49), which raised another question: Why do we have two 1st $p$. possessives, whose distribution is independent of the $[ \pm$ referential $]$ property of the head noun, as is more clearly exemplified in (51):

(51) a. $\mathrm{Nik}_{\mathrm{i}}[\mathrm{ene} / \mathrm{neure} \mathrm{liburua}]_{\mathrm{i}}$ irakurri dut

$$
\text { I-E my book read I-have(-it) }
$$


'I have read my book'

b. Peiok ${ }_{\mathrm{i}}[\text { ene } / * \text { neure liburua }]_{\mathrm{i}}$ irakurri du

Peio-E my book read he-has(-it)

'Peio has read my book'

Admittedly, the Academy recommends the use of neure in sentences such as (51a), but this normative rule is usually not respected by even the best contemporary northern writers, who very rarely utilize it (although the non reflexive ene would have been completely out in older texts, where he distribution of ene and neure was the same as the one of haren and bere as described here).

In fact, the behaviour of ene is not only understandable on functional assumptions: in a sense, the existence of such an element could have been predicted by the absence of correlation between the locality conditions on Basque anaphors studied in this paper. Now consider the following chart:

(52) Local domain / Binding properties:

$\begin{array}{llll}\mathrm{GC}_{\varnothing} & \text { bound } & \text { free } & \text { free } \\ \mathrm{GC}_{1} & \text { (bound) } & \text { bound } & \text { free } \\ \text { pronouns: } & \text { elkar } & \text { bata bertzea } & * \\ & \text { bere burua } & \text { bere } & \text { haren }\end{array}$

Obviously, we cannot have anything that would have to be bound in $\mathrm{GC}_{\varnothing}$ and free in $\mathrm{GC}_{1}$ at the same time. However, another type of pronoun is logically possible: this pronoun would have to be free in $\mathrm{GC}_{\varnothing}$ and either bound of free in $\mathrm{GC}_{1}$, just as the English or Chinese pronominals illustrated in (2b) or (3b) have to. We are therefore entitled to add a fourth column to (52):

$\begin{array}{lllll}\text { (52) Local domain } & \text { / Binding properties: } & & \\ \mathrm{GC}_{\varnothing} & \text { bound } & \text { free } & \text { free } & \text { free } \\ \mathrm{GC}_{1} & \text { (bound) } & \text { bound } & \text { free } & \text { bound or free } \\ \text { reciprocals: } & \text { elkar } & \text { bata bertzea } & * & * \\ \text { reflexives: } & \text { bere burua } & \text { bere } & * & * \\ \text { pronominals: } & & & \text { haren } & \text { ene }\end{array}$

6.2. From this chart, we finally draw the following conclusions:

(a) As can be expected, there are no long-distance reciprocals in Basque (cf. Yang (1983), van Riemsdijk (1985)); more astonishingly, however, one of the two reciprocal expressions, bata bertzea, must not only be bound in the unmarked domain $\mathrm{GC}_{1}$, but it must also be free in the small domain $\mathrm{GC}_{\varnothing}$ - rather than simply either bound or free in it.

(b) The full reflexive expression bere burua must already be bound in the domain which, on Aoun and Chomsky's assumptions, only concerns pronominals - $\mathrm{GC}_{\varnothing}$.

(c) There are no real long distance anaphors in the dialect studied here - although other dialects allow bere to be bound in the root clause, or even to be A-bar bound by an empty topic.

(d) Basque also offers too distinct types of pronominals, with haren which must be free in exactly the same domain as bere must be bound, and ene (and others such as hire 'your' etc.) which must be bound in a narrower domain: they correspond to the marked and unmarked pronominals referred to in section 2.1 .

(e) The distribution of those elements confirms, as I have endeavoured to show, Koster's claim that the minimal binding domain of any type of prounoun must basically be defined as the $\mathrm{X}^{\mathrm{max}}$ which contains its governor, no reference being made to a subject or SUBJECT, the latter only functioning as (counter-)opacity factors ${ }^{26}$.

(f) It is also interesting to note that there is no pair of pronouns of any type (reciprocal, 
reflexive or (strictly) pronominal) which has the same distribution for the two members of its pair; another principle propounded by Koster (1987) is consequently vindicated too, namely the Nonredundancy Principle, (op. cit.: 351 (114)), according to which "Each domain definition defines the binding properties of maximally one type of anaphor (or pronominal)."

\section{Footnotes}

* I would like to dedicate this paper to the memory of the younger Jean Hiriart-Urruty, one of the finest writers in the dialect to be described here. Special thanks are due to Xarlex Videgain for discussing the Basque data with me, and to Jon Ortiz de Urbina for his remarks on a first version of this paper. Needless to say, the usual disclaimers apply as usual.

1. Basque has many dialects; unless otherwise specified, the variety examined here will be the "restricted" or conservative variety of Navarro-Labourdin ill-named "literary" by Lafitte (1962). This is an important restriction, since the southern dialects tcrucially end to blur the distinction I will establish between the two reciprocal expressions elkar and bata bertzea, and allow the "anaphoric" genitive bere to be bound by a (possibly phonetically unrealized) sentence topic.

2. The other case has to do with "understood" subjects such as the tentative PRO which licenses the pronominal in (b) below, as opposed to (a):

(a) They ${ }_{i}$ heard [stories about themselves $]_{i}$

(b) They $_{i}$ heard $\left[\mathrm{PRO}_{\mathrm{j}}\right.$ stories about them $\left.\mathrm{i}\right]$

I shall not deal with such examples in this paper.

3. The clause "is contained in a subject NP" accounts for the fact that possessive anaphors may be embedded in an NP's specifier, as in (b) vs. (a):

(a) Jonek bere xakurra ikusi du

Jon-ERG $b$. dog-ABS seen AUX

'Jon ${ }_{\mathrm{i}}$ has seen $\mathrm{his}_{\mathrm{i} / *_{\mathrm{j}}}$ dog' $^{\prime}$

(b) Jonek bere lagunaren xakurra ikusi du

Jon-ERG $b$. friend's dog seen AUX

'Jon ${ }_{\mathrm{i}}$ has seen his $_{\mathrm{i} / *_{\mathrm{j}}}$ friend's dog'

The notion "SUBJECT's accessibility" straightforwardly accounts for examples of the (b) type - see (6) in the text and footnote 8 below.

4. Thanks to Lobat Houchangnya for these examples.

5. One might wonder whether $(16 \mathrm{c})$ or $(17 \mathrm{~d})$ really are to be taken seriously; this is quite probable, in the light of Kiss's work on binding in Hungarian (see Kiss (1987: 177-178), which, moreover, provides a fully developed hierarchy of oblique cases.

6. The second expression is also attested as bat bertzea (i.e. with no number indication on the numeral bat 'one'), and as batak bertzea where the numeral agrees in (ergative) case with the antecedent. The explicitly singular forms bata and batak are only used when the set referred to by the antecedent NP contains two elements. However, I will only use bata bertzea, sometimes batab., throughout this paper, but it should be considered an abbreviation of bat $(a(k))$ bertzea.

7. Some occurrences of bata bertzea as a direct object in the absolutive case are however attested in 16th century texts. Note also that, from a (purely?) morphological viewpoint, as opposed to a syntactic one, the "coreference" of the entities denoted by the antecedent and the 
reciprocal expressions is not obvious at all, since the latter do not vary in form whatever the person: 1st, 2nd, or 3rd, of their binder. Moreover, as the form of the AUX indicates in (18a) or (19a) - respectively dizki-o-te rather than dizki-e-te, and $\boldsymbol{d}$-ugu lit. 'they have $3 \mathrm{sg}$ ' - these expressions are morphologically singular rather than plural. This question will be taken up in section 5 .

8. To be sure, "distinctness" is not specific enough: what is intended is that they must be disjoint, or that they must "exclude" each other, so as to account for the fact that if an anaphor must neither be, nor be contained in, a subject NP; see footnote 3 .

9. The introduction of Infl among the GC-inducing items in M\&W's work is not too clear, since it relies on the assumption that (a) below [their (6)] has Infl, whereas (b) [their (7)] has not - in other words, that Infinitive counts as Infl in control structures, but not in small clauses.

(a) Alice $_{\mathrm{j}}$ disse a Mario $_{\mathrm{i}}$ di guardare $\mathrm{è̀}_{\mathrm{i} / *_{\mathrm{j}}}$ nello specchio

Alice told Mario to look at Refl in the mirror

(b) Alice $_{j}{\text { vide } \text { Mario }_{i} \text { guardare sè }}_{i / j}$ nello specchio

Alice saw Mario look at Refl in the mirror

It is not obvious that such a move can be made in the Romance languages without some justification being adduced. We will see later that that "secondary subjects", i.e. subjects of secondary predications, do have specific properties, among which, in particular, that of not being able to induce certain GCs.

10. (a) One is not necessarily convinced that certain occurrences of zich are really (PF?) truncations of zichzeilf; (b) since the set of verbs that can take zich rather than (or as well as) zichzelf as a reflexive object is limited, there are good reasons to posit that V+zich VPs really are idiomatic VPs (see Rebuschi (in press-b) for details).

11. The same structural conditions will of course have the same effects, as is illustrated by the following example, where elkar is good if it is locally bound (i.e. if it is coindexed with PRO), but not if it is long distance bound, whilst bata bertzea is out under any interpretation:

(a) Mutilek neskei $_{\mathrm{j}} \quad$ erran diete $\left[\mathrm{PRO}_{\mathrm{j}}\right.$ elkarren $_{*_{\mathrm{i}} \mathrm{j}} /$ bata bertzearen $_{*_{\mathrm{i}} / *_{\mathrm{j}}}$ ikusteko )

boys-the-E girls-the-D said AUX elkar-G one the-other-G to-see

'The boys have told the girls to see each other'

Here, as in (24b), the direct object is in the genitive, an open option since the clause is nominalized.

12. The foregoing relies on the assumption that the genitive ending $-(r) e(n)$ is not a $\mathrm{P}$, but a case suffix. However, since it only appears on the last word of the DP (compare English 's ), one might object that it actually is a $\mathrm{P}$. But this genitive is governed by the locative $\mathrm{P}$ ondoan. It follows that a more detailed account of the facts described should utilize some version of the notion 'chain' or 'dynasty of governors'. In particular, this would account for the fact that if a verb such as jarri 'put' is substituted for ikusi 'see' in the examples of the text, the same effects do not obtain; the reason is obviously that in such a context, the locative $\mathrm{P}$ is subcategorized by the verb; as a consequence, we obtain such a chain of governors, a factor which has as an effect that the whole clause now functions as a binding domain for all the anaphors considered.

13. The approach developed here is descriptively equivalent to the theta-oriented binding theory propounded by Williams $(1987,1989)$. Note that if there is no PRO in locative PPs, the (Extended) Projection Principle is not respected: (a) the P, although bivalent, only has one argument projected; (b) the predicate represented by $\left[\mathrm{P}^{\prime}\right.$ NP-P] or $\left[\mathrm{P}^{\prime} \mathrm{P}-\mathrm{NP}\right]$ is not licensed by a subject. Later on, we shall also see that the presence of a PRO within NPs may have to be 
posited (cf. Chomsky (1986) and the examples in footnote 2 above). Now, whatever the value or strength of Williams's criticism against postulating a PRO in English NPs, we must note that Basque is anyway more Japanese-like, in that for some northern speakers at least, an iteration of genitive "specifiers" is possible, as in (a) (compare Fukui (1986)).

(a) Peioren Mayiren argazkia

Peio-G Mayi-G picture

'Peio's picture of Mayi / Mayi's picture by Peio'

Therefore, it does not seem necessary to say (as Williams surely would) that the obligatorily controlled PRO of the text is in fact a syntactically unrealized external argument of the various heads.

14. I use angled brackets rather than square ones to make it clear that the relation under discussion, although compatible with the existence of Small Clauses, does not presuppose the existence of such structural (or phrasal) entities. Indeed, the predication relation defined in terms of sisterhood might be considered to hold in two distinct cases: trivially for Small Clauses on the one hand, and on the other hand for structures such as (35) where the $V^{\prime}$ would directly dominate a $\mathrm{V}$, an $\mathrm{NP}$, and a $\mathrm{P}$ (or another NP) as the predicated XP.

15. Such contexts would then show that considering the full clause (or the VP containing the subject or its trace) as the minimal $\mathrm{X}^{\mathrm{max}}$ corresponding to an object NP is not a suspicious move that simply consists in reintroducing the suject through the back door.

16. The operativeness of the [+/-stative] property of predicates is an independently wellestablished fact in Basque grammar: see Rebuschi $(1981,1983)$ for instance. If, admittedly, there seems to be an anti-stativity effect for Small Clauses (cf. I saw [you smile / *you resemble your father] ), there is no PRO involved in them...

17. See footnotes 2 and 13 above; here, I must confess that the approach is conceptually more different from Williams's than one might wish, since the subject of the sentence does not "realize" the "Referential theta-rôle" of the dyadic noun lagun 'friend': it actually controls and binds its silent subject. I leave it as a matter for further research to test if anything follows empirically from such divergences.

18. Admittedly, the word "stative" (or "static") is not the best possible one: in fact, only locative and nominal (identificational) predicates should count, since all sentences with an adjectival predicate, such as (a) below, are ungrammatical:

(a) $*$ Nik $<$ [elkarren etsaiak] nekatuak $>$ dauzkat

'I consider $<$ [each other's enemies] tired $>$ '

19. If AGR is a SUBJECT, as in Chomsky (1981), then the ungrammaticality of (40a) above directly ensues, if (i) the lexical condition (32bii) on bata bertzea is taken into account, and (b) no reference is made to the SUBJECT's accessibility. See the final lines of this paper for some more discussion.

20. The following representation, with another PRO inside the sociative NP, will not do, because bere ama as such does not participate directly in the stative predication:

(a) ${ }^{*}$ Peio $_{i}\left[\mathrm{VP}_{\mathrm{i}}\left[\mathrm{PP} \mathrm{PRO}_{\mathrm{i}}\left[\mathrm{P}^{\prime}\left[\mathrm{NP} \mathrm{PRO}_{\text {? }}\left[\right.\right.\right.\right.\right.$ bere $_{\mathrm{i}}$ ama $\left.]\right]$-rekin] dago $]$

21. This is the only interpretation given by the Basque Academy's Grammar, Euskaltzaindia (1986) 
22. The ungrammaticality of:

(a) *Patxi eta Arantxa beren ondoan ziren/zeuden

' $[\mathrm{P} \text {. and } \mathrm{A} .]_{\mathrm{i}}$ were by their ${ }_{i}$ side'

will of course be explained in the same terms.

23. Note that in some sense, the Basque situation is the opposite of the Modern Greek one described by Iatridou (1988): in MG, the possessive is neutral as to the [ \pm reflexive] feature, whereas the head of the reflexive expression, eafton, 'self' has an inherent [+proximate] ferature which is copied onto the possessive.

24. See section 6.1 on the contrast between ene and neure. Let us add that the situation is slightly more complex as far as number is concerned: when the antecedent is plural, the full reflexive expression is either bere-n burua 'their head' (where the $\boldsymbol{- n}$ indicates the number of the antecedent, but the whole expression is singular), or bere-n burua-k 'their heads'. Most speakers do no make any difference between them, but some find the second one more fit if the intended interpretation is distributive rather than collective.

25. Compare the French Il a encore fait des siennes 'he has being doing something stupid again'; tu vas casser ta pipe 'You're going to kick the bucket'; elle y a mis du sien 'she began to pull her weight', etc.

26. Note that we have eventually done away with the notion of "stative predication subject", since this concept merely denotes the controller of the PROs contained in certain well defined PPs and NPs under equally well-defined syntactic conditions: "SPs" as such are not operative as counter-opacity factors - otherwise, sentences like (a) would never be acceptable:

(a) Peiok $_{\mathrm{i}}<$ Miren $_{\mathrm{j}}\left[\right.$ PRO $_{\mathrm{j}}$ bere $_{\mathrm{i} / *_{\mathrm{j}}}$ etsaitzat $]>$ dauka

'P. considers Miren his enemy'

because bere should both be coreferential with, and disjoint from, Miren. Nor can we use the notion "accessible subject/SUBJECT", since in the dialects described here, neither the NP subject nor AGR/Infl allow long-distance binding, as shown by:

(b) Peiok $_{\mathrm{i}}$ dio [haren $\mathrm{i} / \mathrm{j} /$ *bere xakurra hil dela]

'Peio says his dog has died'

\section{References}

Aoun, J. 1985. A Grammar of Anaphora. Cambridge (Mass.): MIT Press.

Chomsky, N. 1981. Lectures on Government and Binding. Dordrecht: Foris.

Chomsky, N. 1986. Knowledge of Language. New York: Praeger.

Enç, M. 1989. 'Pronouns, Licensing, and Binding'; NLLT 7/1, 51-92.

EUSKALTZAINDIA [The Basque Academy] 1985. Euskla gramatika; Lehen urratsak, I; Pamplona, Institución Príncipe de Viana.

Fukui, N. 1986. A Theory of Category Projection and its Applications ; doctoral dissertation, MIT.

Hellan, L. 1988. Anaphora in Norwegian and the Theory of Grammar. Dordrecht, Foris.

Huang, C.T.J. 1983. 'A Note on the Binding Theory'; $L I$ 14/3, 554-561.

Iatridou, S. 1988. 'Clitics, Anaphors, and a Problem of Coindexation'; $L I$ 19/3, 694-703.

Katada, F. 1988. 'What Can Long-Distance Anaphora Say About Operator Systems of Syntax?'; NELS 19.

Kiss, K. E. 1987. Configurationality in Hungarian. [ch. 4: 173-213] Dordrecht: Reidel.

Koster, J. 1985. 'Reflexives in Dutch'; in J. Guéron, H.-G. Obenaurer \& J.-Y. Pollock 
(eds.), Grammatical Representation (Dordrecht, Foris) 141-167.

Koster, J. 1987. Domains and Dynasties. Dordrecht: Foris.

Lafitte, Ps. 1962. Grammaire basque (navarro-labourdin littéraire). Bayonne, Amis du Musée Basque \& Ikas.

Manzini, R. \& Wexler, K. 1987. 'Parameters, Binding Theory, and Learnability'; $L I \quad 18 / 3$, 413-444.

Mohanan, K.P. 1985. 'Remarks on Control and Control Theory'; $L I$ 16/4, 637-648.

Rebuschi, G. 1981. 'Autour des formes allocutives du basque'; in EUSKALTZAINDIA (ed.) Euskalarien Nazioarteko Jardunaldiak (Bilbao, Iker), 307-321.

Rebuschi, G. 1983. 'Autour du parfait et du passif basques'; in EUSKALTZAINDIA (ed.), Piarres Laffiteri Omenaldia - Hommage à Pierre Lafitte (Bilbao \& Pamplona, Iker II), 545-558.

Rebuschi, G. 1986. 'Théorie du liage, diachronie et énonciation: sur les anaphores possessives du basque'; $A S J U$ 20/2, 325-341.

Rebuschi, G. 1988. 'A propos de quelques "universaux" de la théorie du liage'; Verbum $11 / 2,157-185$.

Rebuschi, G. [in press-a]. 'Binding at LF vs. (Counter-)Binding at SS: A Case Study'; in J.A. Lakarra (ed.), Memoriae L. Mitxelenae Magistri Sacrum; San Sebastián, Anejos del Anuario del Seminario de Filología Vasca "Julio de Urquijo" 14.

Rebuschi, G. [in press-b] 'Théorie du liage et autonomie de la syntaxe'; to appear in G. KLEIBER (ed.), Recherches sur l'anaphore [provisional title], Centre de Recherche syntaxique; Metz University.

Riemsdijk, H. Van. 1985. 'Why Long Reciprocals don't Exist'; Theoretical Linguistic Research 2/1, 37-45.

Sigur $f$ sson, H. 1990. 'Icelandic Case-marked PRO and the Licensing of Lexical Apositions'; Working Papers in Scandinavian Syntax 45, 35-82.

Tang, C.J. 1989. 'Chinese Reflexives'; NLLT 7/1, 93-121.

Yang, D.-W. 1983. 'The Extended Binding Theory of Anaphors'; Language Research 19/2, 169- 192. 